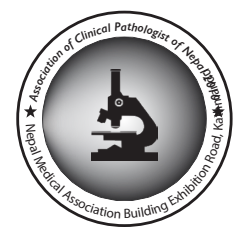

\title{
Histopathological diagnosis of ovarian mass
}

\author{
Shadab Shahali ${ }^{1}$, Mitra Tadayon ${ }^{2}$ \\ ${ }^{I}$ Reproductive health, Avicenna Infertility Clinic Avicenna Research Institute, ACECR, Reproductive Biotechnology Research Center, Tehran, Iran. \\ ${ }^{2}$ Department of Midwifery, Reproductive Health promotion Research Center, Ahvaz Jundishapur University of Medical Sciences, Ahvaz, Iran.
}

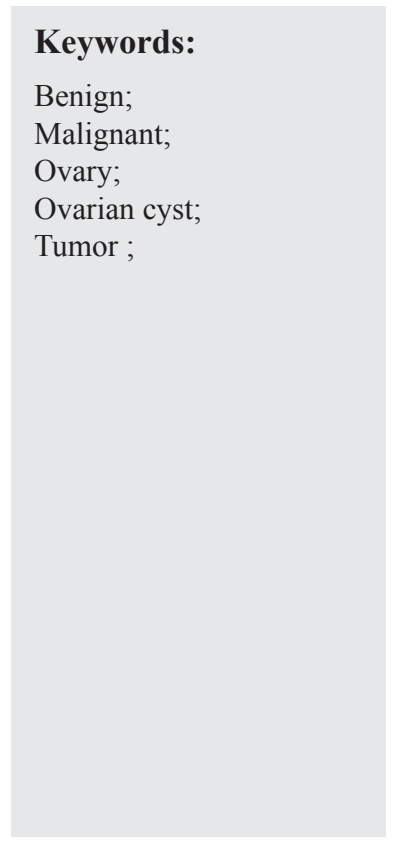

\begin{abstract}
Background: Ovarian cysts are common forms of gynecological problems that can be range from physiological cysts to highly aggressive neoplastic lesions. The purpose of this study was to investigate prevalence and frequency of different histopathological patterns of ovarian lesions and their correlation with various parameters in Ahvaz, Iran.
\end{abstract}

Materials and Methods: This is the retrospective study of patients with the ovarian masses at Ahvaz Imam Khomeini Hospital from 2010 - 2015. The relevant clinical details about the patient were retrieved from hospital data. Clinical characteristics of patients such as patient's age, presenting signs and symptoms, histopathological diagnosis, mass type, mass subtype, size of cysts and ovary which is involved were noted.

Results: Two hundred sixty seven specimens of ovarian tumor obtained for histopathological examination. Of these, $163(61.0 \%)$ were tumor like, $96(36.0 \%)$ were benign tumor and $8(3.0 \%)$ were malignant. The most common tumor like conditions was Corpus luteum cyst (43.4\% cases), among benign and malignant tumors, mature cystic teratoma $(17.2 \%$ of total $)$ and Epithelial tumors $(n=4)$ were most common. There is a statistically significant positive relation between age and various ovarian masses. $(\mathrm{P}=0.002)$. Histopathological diagnosis wasn't correlated with ovarian involvement.

Conclusion: Benign tumors are more common than malignant tumors in all age groups. Germ cell tumors followed by surface epithelial cell tumors are the commonest tumor. Mature cystic teratoma was the most common tumor. Unilaterality is more frequently seen in ovarian tumors and various tumors are seen in various age groups.

\section{Correspondence:}

Mitra Tadayon

Department of Midwifery, Reproductive Health promotion Research Center, Ahvaz Jundishapur University of Medical Sciences, Ahvaz, Iran.

Email: mitratadayon2000@yahoo.com

ORCID ID: 0000-0003-0421-9504

Received : October 17 2017 ; Accepted : December 20 $0^{\text {th }}$ 2017; Published : March $21^{\text {st }} 2018$ Citation: Shadab S, Mitra T. Histopathological diagnosis of ovarian mass. J Pathol Nep 2018;8:12614. doi: 10.3126/jpn.v8i1.19448

Copyright: This is an open-access article distributed under the terms of the Creative Commons Attribution 4.0 International License, which permits unrestricted use, distribution, and reproduction in any medium, provided the original author and source are credited.

\section{INTRODUCTION}

Ovarian cysts are extremely common forms of gynecological problems in females of all age groups, ${ }^{1}$ that can be range from physiological cysts to highly aggressive neoplastic lesions. ${ }^{2}$ A woman's chance of getting ovarian cancer during her lifetime is about $6.0-7.0 \% 3$ and the lifetime risk of ovarian cancer in women with no family history is $1.6 \%{ }^{4}$ Ovarian cancer is the sixth most common female cancer ${ }^{2}$ and the fifth most common leading cause of cancer death in women worldwide ranked after lung and bronchus, breast, colorectal, and pancreatic cancers in United States and causes half of the deaths from female reproductive system. ${ }^{5,6}$ Approximately $80-90 \%$ of all the pathological 
ovarian masses are benign and mostly occur in young women between 20 and 45 years whereas the borderline and malignant tumors are common in postmenopausal women. ${ }^{2,-9}$ Ovarian tumors are divided into three major categories: epithelial, germ cell, and sex cord-stromal tumors.10 and mostly, physiological cysts are follicular and luteal cysts. ${ }^{11}$ The studies showed a large variation and diversity in prevalence, types of ovarian masses and histological patterns of them. ${ }^{4-12}$

Kayastha et al demonstrated the incidence of benign tumor as $90.5 \%$ in Nepal. ${ }^{13}$ Pradhan SB et al showed the incidence of benign ovarian tumors as 86.8 percent. ${ }^{14}$ In Iranian studies the incidence of benign ovarian tumors lies between 67- 69.77 percent. ${ }^{15-16}$

In this study, we aimed to find prevalence and frequency of different histopathological patterns of ovarian lesions and their correlation with various parameters in Ahvaz Imam Khomeini Hospital.

\section{MATERIALS AND METHODS}

This is the retrospective, descriptive study of patients with the ovarian masses at Ahvaz Imam Khomeini Hospital from January 2010 to March 2015. The study was approved by Ahvaz Jundishapur University of Medical Sciences (AJMS) ethical committee. The sampling technique was non probability consecutive sampling. The cases included in the study were women with persistent ovarian cysts, both benign and malignant; the relevant clinical details about the patient were retrieved from hospital data. Clinical characteristics of patients such as patient's age, presenting signs and symptoms, histopathological diagnosis, mass type, mass subtype, size of cysts and ovary which is involved (unilateral or bilateral)were noted. All cases without complete records were excluded from the study.

A total of 643 cases fulfilled the inclusion criteria. We reviewed all the present histopathology reports of the cases in the study (267 cases). The Ovarian cysts were classified according to World Health Organization (WHO) system for ovarian neoplasms. ${ }^{17}$

Data analysis was performed by descriptive statistics (standard deviation, mean, percent, and frequency), chi-square (analysis of qualitative variables), Pearson's correlation and $\mathrm{t}$ test (quantitative variables analysis). Data were analyzed with IBM SPSS statistical software version 22. The significance level for all tests $\mathrm{P}<0.05$ was considered.

\section{RESULTS}

From the total 643 patients who enrolled in the study, only 267 specimens of ovarian tumor obtained for histopathological examination during period of January 2010 to March 2015.

The average age of the patients was $32.41 \pm 12.19(\mathrm{~min}$ : 2, max: 78). The mean age of patients with tumor like
Table 1: Nutritional status of anemic children according to IAP classification

\begin{tabular}{lc}
\hline Mass type & Number (\%) \\
\hline Tumor like conditions: & \\
\hline Simple cyst & $26(9.7)$ \\
\hline Corpus luteum cyst & $116(43.4)$ \\
\hline Endometriosis & $21(7.9)$ \\
\hline Benign tumors: & \\
\hline Serous cyst adenoma & $\mathbf{2 4 ( 9 . 0 )}$ \\
\hline Mature cystic teratoma & $\mathbf{4 6}(17.2)$ \\
\hline Mucinous cystadenoma & $25(9.4)$ \\
\hline Fibrothecoma & $1(0.4)$ \\
\hline Malignant tumors: & \\
\hline Epithelial tumors & $4(1.5)$ \\
\hline Germ cell tumors & $1(0.4)$ \\
\hline Sex cord stromal tumors & $2(0.7)$ \\
\hline Sarcoma & $1(0.4)$ \\
\hline Total & $\mathbf{2 6 7 ( 1 0 0 )}$ \\
\hline
\end{tabular}

conditions was $30.48 \pm 10.66$, with benign tumors was $35.46 \pm 13.79$ and for women with malignant tumors, it was $35.12 \pm 14.7$ years.

The commonest presenting symptom in patients was abdominal pain (247 cases, 92.5\%) followed by abdominal mass ( 7 patients, 2.6\%), abnormal uterine bleeding (7 patients, 2.6\%) and abdominal distention (6 cases, 2.2\%).

Of these, 163(61.0\%) were tumor like, 96(36.0\%) were benign tumor and $8(3.0 \%)$ were malignant. In our study, we did not encounter any case of ovarian tumor with borderline malignancy. The most common tumor like conditions was Corpus luteum cyst ( $43.4 \%$ cases), among benign and malignant tumors, mature cystic teratoma ( $17.2 \%$ of total) and Epithelial tumors (4 patients) were most common. (Table 1)

Various ovarian masses are seen in various age groups which are shown in table 2. Most of the ovarian tumor was found in 21- 30 years age group (96 patients, 35.95\%) and there is a statistically significant positive relation between age and various ovarian masses. (P value:0.002)

Among 267 patients, $89.5 \%$ were unilateral either right $(51.3 \%)$ or left $(38.2 \%)$ and $10.5 \%$ were bilateral. Histopathological diagnosis wasn't correlated with ovarian involvement which is shown in table3. (P value: 0.43 )

\section{DISCUSSION}

Ovarian lesions are one of the most common specimen that are received by pathologists ${ }^{14}$ and because of the similar clinical presentation and non-specific symptoms of all lesions of ovary, it is important to differentiate between physiological and pathological cyst for further management. ${ }^{18}$ 
Table 2. Age wise distribution of ovarian masses

\begin{tabular}{lccccc}
\hline \multirow{2}{*}{ Age Group (Years) } & \multicolumn{3}{c}{ Number (\%) } & Total n (\%) & P value \\
\cline { 2 - 4 }$\leq 20$ & Tumor like conditions & Benign tumors & Malignant tumors & & $34(100)$ \\
$21-30$ & $23(67.6)$ & $10(29.4)$ & $1(2.9)$ & $96(100)$ \\
$31-40$ & $67(69.8)$ & $26(27.1)$ & $3(3.1)$ & $79(100)$ & $36(100)$ \\
$41-50$ & $46(58.2)$ & $32(40.5)$ & $1(1.3)$ & $15(100)$ & $7(100)$ \\
\hline $51-60$ & $21(58.3)$ & $14(38.9)$ & $2(13.3)$ & 0.002 \\
\hline 60 & $4(26.7)$ & $9(60.0)$ & $0(0)$ & $\mathbf{2 6 7 ( 1 0 0 )}$ \\
\hline Total & $2(28.6)$ & $5(71.4)$ & $\mathbf{8 ( 3 . 0 \% )}$ & \\
\hline
\end{tabular}

Table 3. Histopathological diagnosis and site of involvement.

\begin{tabular}{lccccc}
\hline & \multicolumn{3}{c}{ Number (\%) } & Total n (\%) & P value \\
\cline { 2 - 4 } Right ovary & Tumor like conditions & Benign tumors & Malignant tumors & & $137(100)$ \\
Left ovary & $90(65.7)$ & $43(31.4)$ & $4(2.9)$ & $4(3.9)$ & $102(100)$ \\
Bilateral & $57(55.9)$ & $41(40.2)$ & $0(0)$ & $28(100)$ & 0.43 \\
\hline Total & $16(57.1)$ & $12(42.9)$ & $\mathbf{8 ( 3 . 0 )}$ & $\mathbf{2 6 7 ( 1 0 0 )}$ \\
\hline
\end{tabular}

In our study the age of the patients ranged from 2-78 years. The age range varied in different studies. In Chanu et al, the age range was $18-83$ years ${ }^{19}$ and in the Danish et al, study it was $5-72$ years. ${ }^{18}$ The age range in other study done in Iran was $11-85$ years. ${ }^{20}$

In the present study, the incidence of tumor like conditions was $61.0 \%$, and from all $39 \%$ of ovarian tumor obtained from histopatological examination, of which, benign tumors were $92.3 \%$ and malignant tumors were $7.7 \%$. Similar to our finding Hassani et al reported $91.4 \%$ benign tumors and $8.6 \%$ malignant tumours. ${ }^{20}$ In a study done by Khatri et al, $68.0 \%$ of ovarian tumors were benign and $32.0 \%$ were malignant. ${ }^{21}$ The difference is probably because our study was undertaken in a referral hospital and malignant tumors diagnosed before surgery were referred to this center.

Most common benign tumor was mature cystic teratoma followed by serous cyst adenoma. Yogambal et al, ${ }^{22}$ Yasmin et $a{ }^{23}$ and Hassani et $\mathrm{al}^{20}$ found that the most common benign tumor was serous cyst adenoma which followed by mature cyst teratoma. Ahmed et $\mathrm{al}^{24}$ and Pradhan et $\mathrm{al}^{14}$ studies showed benign cystic teratoma was the commonest benign tumor.

In our study the most common presenting symptom was abdominal pain followed by abdominal mass and abnormal uterine bleeding. Similarly, Yogambal et al, ${ }^{22}$ Yasmin et al, ${ }^{23}$ and Rashid et $\mathrm{al}^{25}$ observed abdominal pain followed by abdominal mass was the commonest presenting symptom. In contrast to our findings, S.N et al mentioned that menstrual irregularities/ abnormal vaginal bleeding followed by pain in abdomen was the most common clinical symptoms in women with ovarian tumors. ${ }^{12}$

In our study, $89.5 \%$ tumors were unilateral and $10.5 \%$ were bilateral. The incidence of unilaterality in S.N et al study $(78.18 \%)$ was little less than our study. ${ }^{12}$ In a study done by
Garg et al majority of the tumors were unilateral $(95.3 \%){ }^{9}$

In our study maximum number of ovarian tumors was noted in 21- 30 years age group which concord with the study done by Pradhan et al. ${ }^{14}$ However, Garg et al, ${ }^{9}$ and Jindal et al. ${ }^{26}$ observed that most common ovarian tumors were in 30-50 years age group.

\section{CONCLUSION}

In our study, benign tumors are more common than malignant tumors in all age groups. Germ cell tumors followed by surface epithelial cell tumors are the commonest class of tumors. Mature cystic teratoma was the most common tumor in our study followed by serous cystadenoma. Unilaterality is more frequently seen in ovarian tumors and various tumors are seen in various age groups.

\section{Conflict of interest: None}

Acknowledgement: This study was supported by Ahvaz Jundishapur University of Medical Sciences. Researchers wish to thank all university officials and participants in this study.

\section{REFERENCES}

1. Swamy G, Satyanarayana N. Clinicopathological analysis of ovarian tumors-A study on five years samples. Nepal Med Coll J. 2010;12:221-3. Crossref

2. Zubair M, Hashmi SN, Afzal S, et al. Ovarian Tumors: A Study of 2146 Cases at AFIP, Rawalpindi, Pakistan. Austral - Asian Journal of Cancer. 2015;14:21- 6

3. Jha R, Karki S. Histological pattern of ovarian tumors and their age distribution. Nepal Med Coll J. 2008;10:81-5. Crossref

4. Makwana H, Maru A, Lakum N, Agnihotri A, Trivedi N, Joshi J. The relative frequency and histopathological pattern of ovarian masses - 11 year study at tertiary care centre. Int. J. med. Sci. public health 2014;3:81-4 
5. Pradhan A, Sinha A, Upreti D. Histopathological patterns of ovarian tumors at BPKIHS. Health Renaissance. 2012;10:87-97. Crossref

6. U.S. Cancer Statistics Working Group. United States Cancer Statistics: 1999-2014 Incidence and Mortality Web-based Report. Atlanta: U.S. Department of Health and Human Services, Centers for Disease Control and Prevention and National Cancer Institute; 2017. Crossref

7. Iqbal J, Aurangzaib, Naseem A, Shahid A. Pattern of Ovarian Pathologies. JRMC; 2013;17:113-5

8. Al-Musalhi K, Al-Kindi M, Ramadhan F, Al-Rawahi T, Al-Hatali K, Mula-Abed W-A. Validity of Cancer Antigen-125 (CA-125) and Risk of Malignancy Index (RMI) in the Diagnosis of Ovarian Cancer. Oman Med J 2015;30:428-34. Crossref

9. Garg N, Anand AS, Annigeri C. Study of histomorphological spectrum of ovarian tumours. Int. J. Med. Sci. 2017;3:12-20

10. Kline RC, Bazzett-Matabele LB. Adnexal masses and malignancies of importance to the colorectal surgeon. Clin Colon Rectal Surg. 2010;23:63-71. Crossref

11. Dhakal R, Makaju R, Bastakoti R. Clinico-morphological Spectrum of Ovarian Cystic Lesions. Kathmandu Univ Med J 2016;53:13-16

12. S.N. K, N.V. D, P.N. D, D.B. N, K.H. S. Clinico-Histopathological Analysis of Neoplastic and Non-Neoplastic Lesions of the Ovary: A 3-Year Prospective Study in Dhule, North Maharashtra, India. J Clin Diagn Res 2014;8:FC04-FC07

13. Kayastha S. Study of ovarian tumors in Nepal Medical College Teaching Hospital. Nepal Med Coll J 2009;11:200-2. $\underline{\text { Crossref }}$

14. Pradhan SB, Chalise S, Pradhan B, Maharjan S. A study of ovarian tumors at Kathmandu medical college teaching hospital. J Pathol Nep 2017;7:1188-91. Crossref

15. Jafari Shobairy M, Fardi Azar Z, Afkari A. Pathologic evaluation of ovarian masses, from the point of age and clinical manifestation. Tabriz med univ J; 2003;37:10-5. [Persian]

16. Kashanian M, Kamalian N, Afsharpad K. Frequency and Age Distribution of Ovarian Tumors in Shariati Hospital over a 20-year
Period. RJMS. 2005;11:1021-8. [Persian]

17. Scully R.Histological typing of ovarian tumours. Geneva, World Health Organization.1999. Crossref

18. Danish F, Khanzada MS, Mirza T, Aziz S, Naz E, Khan MN. Histomorphological Spectrum of Ovarian Tumors with Immunohistochemical Analysis of Poorly or Undifferentiated Malignancies. GJMS. 2012;10:209-15.

19. Chanu SM, Dey B, Raphael V, Panda S, Khonglah Y. Clinicopathological profile of ovarian cysts in a tertiary care hospital. Int J Reprod Contracept Obstet Gynecol. 2017;6:4642-5. Crossref

20. Hasani, M., Alizadeh, S., Bastami, P., Soheyli, F. The frequency of ovarian masses and lesions in different age categories in Khorram Abad (1381-1391). The Iranian Journal of Obstetrics, Gynecology and Infertility, 2014;17:9-16.

21. Khatri R. Clinicopathological Analysis of Ovarian Tumours at Birendra Military Hospital. Medical Journal of Shree Birendra Hospital.2011;10:26-31.

22. Yogambal M, Arunalatha P, Chandramouleeswari K, Palaniappan V. Ovarian tumours- Incidence and distribution in a tertiary referral center in south India. IOSR-JDMS. 2014;13:74-80. Crossref

23. Yasmin S, Yasmin A, Asif M. Clinicohistological pattern of ovarian tumours in Peshawar region. J Ayub Med Coll Abbottabad. 2008;20:11-3. Crossref

24. Ahmed Z, Kiyani N, Hasan S. H, Muzaffar S. Gill M. S. Histological Patterns of ovarian neoplasia. J Pak Med Assoc 2000;50:416-9.

25. Rashid S, Sarwar G, Ali A. A clinicopathological Study of ovarian cancer. Departments of Radiotherapy and oncology Sir Ganga Ram Hospital and Mayo Hospital Lahore. J Pak Med Assoc 1998;36;11725 .

26. Jindal U. Pattern of ovarian neoplasm in rural population: a five year study from tertiary care hospital. JEMDS 2014;3:2033-9. $\underline{\text { Crossref }}$ 